\title{
On Reading and Using the Tenth Amendment
}

Reports of the death of the Tenth Amendment ${ }^{1}$ have been greatly exaggerated. Though the doctrine of "state sovereignty" articulated in $\mathrm{Na}$ tional League of Cities $v$. Usery ${ }^{2}$ has been radically narrowed, ${ }^{3}$ the return of the Amendment to its previous status as a "truism" is no more inevitable than it would be wise. The assertion that state power can impose an affirmative limitation on federal action remains provocative yet ill-defined. Recent cases have, moreover, revealed a tension between the protection of state sovereignty and the vindication of the federal rights of state citizens. ${ }^{5}$

1. "Powers not delegated to the United States by the Constitution, nor prohibited by it to the States, are reserved to the States respectively, or to the people." U.S. CoNST. amend. X.

2. National League of Cities v. Usery, 426 U.S. 833 (1976) (application of Fair Labor Standards Act to state and municipal employees struck down as violation of Tenth Amendment). National League of Cities touched off a vigorous debate concerning the meaning and scope of the doctrine articulated. See, e.g., Barber, National League of Cities: New Meaning for the Tenth Amendment?, 1976 SUP. CT. REv. 161 (case articulates no coherent conception of state sovereignty); Michelman, States' Rights and States' Roles: Permutations of Sovereignty in National League of Cities v. Usery, 86 YALE L.J. 1165 (1977) (case recognizes an individual right to "essential government services"); Tribe, Unraveling National League of Cities: The New Federalism and Affirmative Rights to Essential Governmental Services, 90 HARv. L. REv. 1065 (1977) (same); Note, Redefining the National League of Cities State Sovereignty Doctrine, 129 U. PA. L. REv. 1460 (1981) (case allocates responsibility for legislative decisions to appropriate level of government).

3. See FERC v. Mississippi, 456 U.S. 742 (1982) (Public Utility Regulatory Policies Act does not violate Tenth Amendment); United Transp. Union v. Long Island R.R., 455 U.S. 678 (1982) (application of Railway Labor Act to employees of state-owned railroad does not violate Tenth Amendment); Hodel v. Virginia Surface Mining Control \& Reclamation Ass'n, 452 U.S. 264 (1981) (Surface Mining Control \& Reclamation Act of 1977 does not violate Tenth Amendment). The National League of Cities doctrine suffered its greatest curtailment to date in last Term's decision in EEOC v. Wyoming, 103 S. Ct. 1054 (1983). There, the Court held that the application to the states of the Age Discrimination in Employment Act-a measure similar in several respects to the Fair Labor Standards Act invalidated in National League of Cities-did not violate the Tenth Amendment. This Term, the Court may have the opportunity to hold even the Fair Labor Standards Act applicable to the states in San Antonio Metropolitan Transit Auth. v. Donovan, 557 F. Supp. 445 (W.D. Tex. 1983), prob. juris. noted, 52 U.S.L.W. 3261 (U.S. Oct. 3, 1983), a challenge to the application of minimum wage and overtime provisions of the Act to San Antonio's municipal bus drivers.

4. See United States v. Darby, 312 U.S. 100, 124 (1941) (Tenth Amendment a "truism" which imposes no limitation on congressional power).

5. See, e.g., Paul v. Davis, 424 U.S. 693, 701 (1976) (reluctance to federalize state tort law results in denial of recovery for state-imposed harms to reputation); Rizzo v. Goode, 423 U.S. 362, 379-80 
The Tenth Amendment provides the most appropriate point of departure for examining such questions, as it is the only clause to outline a relation among the federal government, the states, and their citizens. Its ambiguous language, however, eludes all but the most careful analysis.

One promising approach is suggested by the Ninth Amendment, ${ }^{6}$ a provision that bears a marked similarity to the Tenth. Although this amendment lapsed into obscurity after a brief period of adjudication following Griswold $v$. Connecticut, ${ }^{7}$ it is now enjoying a modest renaissance under the able sponsorship of Charles Black..$^{8}$ The structure and relationship analysis that Black has brought to its construction is even better suited to the content of the Tenth Amendment. The historical development of these two provisions shows the advantage of the structural approach over the methods previously used to construe the Tenth Amendment.

\section{Tenth Amendment: Light fRom the Ninth}

From the time of their framing, language and structure marked these two amendments as distinct from other clauses of the Constitution and as similar to each other. ${ }^{\circ}$ Like the first eight amendments, they articulated limits upon the power of the federal government. But unlike the first eight, which set out specific substantive guarantees, the Ninth and Tenth addressed broad residual categories: the rights and powers not enumerated in the Constitution. And unlike many of the preceding amendments, which issued imperatives to the branches of government, these merely pointed to the existence of powers outside the federal government. ${ }^{10}$

(1976) (principles of federalism limit availability of injunctive relief against police violence).

6. "The enumeration in the Constitution, of certain rights, shall not be construed to deny or disparage others retained by the people." U.S. CoNST. amend. IX.

7. 381 U.S. 479 (1965).

8. See C. Black, Decision According To LAw (1981) (structure and relationship analysis applied to Ninth Amendment) [hereinafter cited as Decision According To LAw]; C. BLACK, Structure AND Relationship IN Constitutional LAW (1969) (structure and relationship analysis developed in context of Ninth and other Amendments) (hereinafter cited as STRUCTURE AND Relationship]; C. Black, On Reading and Using the Ninth Amendment (1983) (unpublished manuscript available at Yale Law School Library); see also J. ELY, Democracy AND Distrust 34-41 (1980) (Ninth Amendment may be used as textual basis for individual rights which have not yet been defined); Berger, The Ninth Amendment, 66 CoRnell. L. Rev. 1 (1980) (contemporary efforts to use Ninth Amendment to increase federal enforcement power against states subvert original purpose of provision limiting federal government); Caplan, The History and Meaning of the Ninth Amendment, 69 VA. L. REv. 223 (1983) (history shows Ninth Amendment intended to protect rights guaranteed by laws of states); Van Alstyne, Slouching Toward Bethlehem with the Ninth Amendment (Book Review), 91 YALE L.J. 207 (1981) (finding Black's argument in Decision According to LAw that Ninth Amendment provides justiciable source of unenumerated rights to be largely unpersuasive).

9. In articles both before and after Griswold, commentators have pointed to this structural similarity. See Berger, supra note 8, at 2-3 (points to language to support conclusion that both amendments designed to underscore limited nature of federal government); Redlich, Are There "Certain Rights . . . Retained by the People"?, 37 N.Y.U. L. REv. 787, 804-05 (1962) (similarity of language supports interpretation that both amendments protect unenumerated fundamental rights).

10. The debates which preceded adoption of the Bill of Rights also illustrate the distinctive char- 
The distinct character of these amendments was underscored in the early years of their construction. Raised as a bar to federal action, the amendments were held inapplicable where the government had acted under a granted power. ${ }^{11}$ In this respect they differed from the other clauses of the Bill of Rights, many of which were held sufficient to defeat governmental action under a granted power. ${ }^{12}$ The paths of the two amendments diverged, however, when the Ninth Amendment was reborn as a source of substantive rights in Griswold v. Connecticut." "The Ninth Amendment," Justice Goldberg stated in concurrence, "shows the intent of the Constitution's authors that other fundamental personal rights should not be denied such protection . . . simply because they are not specifically listed in the first eight constitutional amendments."14 To de-

acter of the Ninth and Tenth Amendments. While most clauses of the Constitution established the rights and powers of the government and its citizens, the last two amendments sought to allay concerns that the Framers feared might defeat the Constitution. The Ninth Amendment addressed the concern that the canon "what is expressed excludes what is not" might be read into the Bill of Rights. See, e.g., Berger, supra note 8, at 7; Note, The Uncertain Renaissance of the Ninth Amendment, 33 U. ChI. L. REv. 814, 821 (1966). The Tenth Amendment responded to "fears that the new national government might seek to exercise powers not granted, and that the states might not be able to exercise fully their reserved powers." United States v. Darby, 312 U.S. 100, 124 (1941).

11. Sep United Pub. Workers v. Mitchell, 330 U.S. 75 (1947). The Court explained:

The powers granted by the Constitution to the federal government are subtracted from the totality of sovereignty originally in the states and the people. Therefore, when objection is made that the exercise of a federal power infringes upon rights reserved by the Ninth and Tenth Amendments, the inquiry must be directed toward the granted power under which the action of the Union was taken. If the granted power is found, necessarily the objection of invasion of those rights, reserved by the Ninth and Tenth Amendments, must fail.

Id. at 95-96. Mitchell's simultaneous consideration of the Ninth and Tenth Amendments, another indication of their similarity, was typical during this period. See, e.g., Tennessee Elec. Power Co. v. TVA, 306 U.S. 118, 143-44 (1939) (TVA's competitive sale of electrical power does not violate Ninth or Tenth Amendment); Ashwander v. TVA, 297 U.S. 288, 330-31 (1936) (governmental authority to dispose of property constitutionally acquired does not violate Ninth or Tenth Amendment). The Court's inquiry generally assimilated the rights secured by the Ninth Amendment to the powers protected by the Tenth. See Bertelsman, The Ninth Amendment and Due Process of Law-Toward a Viable Theory of Unenumeraled Rights, 37 U. CiN. L. REv. 777, 781 (1968) (Ninth Amendment "equated with" Tenth Amendment). Efforts to limit the federal commerce power by invoking the Tenth Amendment alone were rarely more successful than attempts to raise both amendments together. Compare NLRB v. Jones \& Laughlin Steel Co., 301 U.S. 1, 37 (1937) (National Labor Relations Act of 1935 does not exceed congressional power to regulate commerce, where regulated activities, arguably intrastate in nature and reserved to state regulation by Tenth Amendment, have "close and substantial relation to interstate commerce") with Hammer v. Dagenhart, 247 U.S. 251, 271-73 (1918) (Act proscribing use of child labor exceeds Congressional power to regulate commerce, since it regulates manufacturing local in nature and reserved to state regulation by Tenth Amendment).

12. This distinction was illuminated in Roth v. United States, 354 U.S. 476 (1957), which involved a challenge to a postal regulation prohibiting pornography. The Roth Court stated that the First Amendment-though ultimately inapplicable - was capable of defeating a granted power, while the Ninth and Tenth Amendments were not. Id. at 492; see also Leary v. United States, 395 U.S. 6 (1969) (presumption in criminal statute that possessor of marijuana is deemed to know of its unlawful importation violates Fifth Amendment); United States v. Jackson, 390 U.S. 570 (1968) (death penalty clause of Federal Kidnaping Act violates Sixth Amendment).

13. 381 U.S. 479, 486 (1965) (Goldberg, J., concurring).

14. Id. at 492 . 
fine the rights thus protected became the task of the opinions and articles that followed. ${ }^{15}$

Jurists approached this task in two ways. Some attempted to define the content of the Ninth Amendment by reference to normative political philosophy, taking their bearings from natural law theories. ${ }^{16}$ The amendment, many scholars claimed, had been framed against a tradition of secular and religious natural law; ${ }^{\mathbf{1 7}}$ moreover, the "concept of ordered liberty," a derivative of natural law theories, had played a part in the due process adjudication of the twentieth century ${ }^{18}$ Finally, natural law's account of the rights that inhere in "men as men" seemed a logical complement to the Bill of Rights' account of the rights that inhere in men as members of the American polity. Natural law did not, however, provide the standards that its proponents had hoped. Some scholars refused to accept the existence of rights that inhere in "men as men"18; others disputed their influence on the thought of the founders. ${ }^{20}$ Most agreed that natural law, if it did exist, was sufficiently indeterminate to leave unbounded discretion in the hands of unelected judges. ${ }^{21}$

15. See, e.g., Olff v. East Side Union High School Dist., 404 U.S. 1042, 1044 (1972) (Douglas, J., dissenting from denial of certiorari) (imposition of rules concerning long hair implicates Ninth Amendment right to free choice in personal habits); Mindel v. United States Civil Serv. Comm'n, 312 F. Supp. 485, 488 (N.D. Cal. 1970) (termination of postal employee for cohabitation infringes employee's Ninth Amendment right to privacy); Hooper v. Gooding, 282 F. Supp. 624, 627 (D. Ariz. 1968) (failure of judge to close preliminary hearing after inadmissible evidence was admitted infringes defendant's Ninth Amendment right to privacy). For the contributions of commentators, see Berger, supra note 8 (Ninth Amendment should not be employed by federal government against the states); Towe, Natural Law and the Ninth Amendment, 2 Pepperdine L. Rev. 270, 291 (1975) (Ninth Amendment should protect values deemed fundamental "by society at the time"); Van Loan, Natural Rights and the Ninth Amendment, 48 B.U.L. REv. 1, 43-45 (1968) (Ninth Amendment can be used to protect rights inferrable by analogy from enumerated rights).

16. See Griswold v. Connecticut, 381 U.S. 479, 493 (1965) (Goldberg, J., concurring) (quoting Powell v. Alabama, 287 U.S. 45, 67 (1932)) (Ninth Amendment protects those "fundamental principles of liberty and justice which lie at the base of all our civil and political institutions"); B. PATTERson, The Forgotten Ninth Amendment 3 (1955) (Ninth Amendment should be used to protect "unenumerated inherent human rights with which individuals are naturally endowed").

17. Sep Bertelsman, supra note 11, at 793 (framers thought "basic human rights" were "derived from the Creator"); Van Loan, supra note 15, at 11-12 (framers influenced by "religious natural law doctrines" and "secular natural law theorists" of England).

18. See, e.g., Griswold v. Connecticut, 381 U.S. 479, 500 (1965) (Harlan, J., concurring) (quoting Palko v. Connecticut, 302 U.S. 319, 325 (1937)) (Fourteenth Amendment's due process clause protects marital privacy because it is "implicit in the concept of ordered liberty" "); Poe v. Ullman, 367 U.S. 497, 539-45 (1961) (Harlan, J., dissenting) (same standard); Palko v. Connecticut, 302 U.S. 319, 325-28 (1937) (Fifth Amendment protection against double jeopardy not applicable against states because not "implicit in the concept of ordered liberty"), oterruled, Benton v. Maryland, 395 U.S. 784 (1969).

19. See, e.g., Towe, supra note 15, at 273-74 (surveying arguments of critics that natural law not susceptible of proof or demonstration and may actually be disguise for individual preferences).

20. Cf. R. Berger, Government by Judiciary 250 (1977) (Framers did not envision government by principles of "natural law" used by Warren Court to justify activism); Bork, Neutral Principles and Some First Amendinent Problems, 47 IND. L.J. 1, 4-8 (1971) (Constitution and inferable intent of Framers provide no basis for identifying "fundamental" values).

21. See J. ELy, supra note 8, at 50 ("YY]ou can invoke natural law to support anything you 
Other jurists favored an empirical approach. These commentators asked whether the right in question was supported by the system of moral beliefs that prevailed in contemporary society. ${ }^{22}$ Despite the appearance of greater determinacy and objectivity, ${ }^{23}$ advocates of empirical analysis fared little better than their normative counterparts. Proponents found it difficult to explain how judges would discern "conventional morality" without relying on their own moral beliefs. ${ }^{24}$ They also had to confront the difficulty of deciding which beliefs constituted "conventional morality" in an irreducibly pluralist American society. ${ }^{25}$ More importantly, empirical analysts faced a problem of judicial competence. Distinguished by their scholarly training and insulation from popular sentiment, ${ }^{28}$ judges would be at a distinct disadvantage in extracting from the range of conflicting sentiments the prevailing morality.

In the face of such obstacles, the number of cases in which the Ninth Amendment was adverted to gradually declined ${ }^{27}$ Yet the lessons of this period appear to have been lost on many of those who delivered them: The Ninth Amendment had scarcely begun its decline when the Court handed down its opinion in National League of Cities. ${ }^{28}$ In that case, at least one judicial critic of Justice Goldberg's enterprise ${ }^{29}$ began to con-

want."); R. UNGER, KNowledge AND Politics 241 (1975) (conceptions of "universal human nature" either too vague to be helpful in guiding moral and political action or too specific to be considcred universal).

22. Wellington, Common Law Rules and Constitutional Double Standards: Some Notes on Adjudication, 83 YALE L.J. 221, 244 (1973) (defining conventional morality as "society's set of moral principles and ideals").

23. Sep Towe, supra note 15 , at 290 ("despite disagreements, sufficient general consensus can be achieved"); Wellington, supra note 22, at 245-46 (describing "conventional morality" as "knowable to socialized persons" through "method of philosophy").

24. See J. ELY, supra note 8, at 64-67. Ely describes this tendency and its inevitable consequence: "[B]y viewing society's values through one's own spectacles . . . one can convince oneself that some invocable consensus supports almost any position a civilized person might want to see supported." Id. at 67.

25. Sep id. at 63-64 ("a growing literature ... argues that in fact there is no consensus to be discovered"); $f f$. B. Ackerman, Private Property and the Constitution 96 (1974) ("[T]he social world is a big, big place; yet . . . the requisites of legal decision demand that a complex social web be reduced to a single line.").

26. SeP J. ELY, supra note 8, at 64-65 ("stampede of state reenactments of death penalty" following Furman v. Georgia only one example of judicial inability to discern moral consensus). For a more comprehensive discussion of judicial competence, see A. Bickel, The Least Dangerous Branch 23-28 (1962) (judiciary distinguished by political detachment and training in logical modes of reasoning).

27. A LEXIS computer search of Supreme Court and federal circuit court cases reveals a precipitous rise and fall in the number of cases in which the Ninth Amendment was raised between 1965 and 1975. From a total of two cases in 1965-67, the number rose to 33 in 1968-71 and declined to 17 in 1973-75.

28. 426 U.S. 833 (1976).

29. Justice Rehnquist, for example, has opposed the use of the Ninth Amendment to protect even the right of privacy, and argued that its widespread application would lead to activism and arbitrariness in adjudication. Sep Richmond Newspapers, Inc. v. Virginia, 448 U.S. 555, 604-05 (1980) (Rehnquist, J, dissenting). Justice Rehnquist sarcastically compared the attitude of the Court, in invoking the Sixth, Ninth, and Fourteenth Amendments, to that of the Lord Chancellor in Gilbert 
strue the Tenth Amendment with the same methods that had been applied to the Ninth.

One approach, set out in National League of Cities and relied upon in succeeding cases by the Supreme Court, asked whether an enactment interferes with "undoubted attribute[s] of state sovereignty." which stressed the powers that inhere in "States as States,"31 mirrored the natural law discovery of the rights that inhere in "men as men." Like the natural law approach, however, it has encountered difficulties of application that render it almost completely inadministrable.

The judge who embarks on this interpretive enterprise must do so without the guidance of an historical or theoretical tradition. Not only did the delegates to the constitutional convention lack any determinate notion of the nature or scope of state power; many of the greatest disputes of the period concerned the proper arrangement of state and federal powers. ${ }^{32}$ Modern efforts to define the inherent attributes of state sovereignty have encountered similar difficulties. The distinction between political and economic activities used by some courts to define state sovereignty ${ }^{33}$ has proved a blunt instrument for which there is little hope of refinement. ${ }^{\text {s4 }}$ Nor are courts likely to discover a substitute for the political/economic

\section{and Sullivan's "Iolanthe":}

The Law is the true embodiment

Of everything that's excellent,

It has no kind of fault or flaw,

And I, my Lords, embody the Law.

Id. at 604; $c$. Roe v. Wade, 410 U.S. 113, 173 (1973) (Rehnquist, J., dissenting) (penumbral approach to privacy encourages review so broad as to be more legislative than judicial).

30. 426 U.S. 833, 845 (1976).

31. Id.; sep also FERC v. Mississippi, 456 U.S. 742, 763-64 n.28 (1982) (Public Utility Regulatory Policies Act does not regulate "States as States"); Hodel v. Virginia Surface Mining \& Reclamation Ass'n, 452 U.S. 264, 287 (1981) (Surface Mining Control \& Reclamation Act does not regulate "States as States").

32. See Berns, The Meaning of the Tenth Amendment, in A Nation of States 139, 139-41 (R. Goldwin ed. 1961) (controversy over effect of Constitution on state power dominated debate over its ratification and continued after founding of new republic); Note, Separating Myth from Reality in Federalism Decisions: A Perspectite on American Federalism Past and Present, 35 VAND. L. REv. $161,167-71$ (1982) (Founders differed significantly on question of state power).

33. See FERC v. Mississippi, 456 U.S. 742 (1982) (federal regulation of private enterprise is preemptive activity which does not implicate Tenth Amendment); Hodel v. Virginia Surface Mining \& Reclamation Ass'n, 452 U.S. 264 (1981) (same); National League of Cities v. Usery, 426 U.S. 833 (1976) (provision of "basic services" is statelike activity that requires Tenth Amendment protection); Public Serv. Co. v. FERC, 587 F.2d 716 (5th Cir. 1979) (regulation of state oil and gas business similar enough to regulation of private enterprise not to implicate Tenth Amendment).

34. In FERC v. Mississippi, 456 U.S. 742 (1982), for example, the Court divided in confusion over whether the regulation of utilities by a state legislative commission was a "statelike"-i.e., political-or an economic activity. The majority argued that because it was a private enterprise whose regulation was being contested, "[state] decisionmakers must give preclusive effect to federal enactments . . . no matter what the strength of the competing local interests." Id. at 766. The dissent reached a different conclusion by focusing not on the regulated activity but on the body previously responsible for its regulation: "While the statute's ultimate aim may be the regulation of private utility companies, PURPA addresses its commands solely to the States." Id. at 779 (O'Connor, J., dissenting). 
theory of statehood. Because the allocation of powers to the states is, in many areas of policy, an ad hoc, pragmatic choice, ${ }^{35}$ few normative theorists have attempted to identify the powers most appropriately associated with statehood. ${ }^{36}$ The absence of even the theoretical guidance available under the Ninth Amendment increases the judge's discretion.

Perhaps because of this danger, many judges have preferred to apply an empirical test. This standard, proposed in National League of Cities but championed primarily by the lower courts, inquires whether a congressional enactment interferes with "traditional state functions." ${ }^{\text {37 }}$ In applying this test, judges have asked which functions have historically been performed by the states, or which allocations of power to the states have worked successfully in the past.

The greater determinacy that this approach appeared to promise has proved largely illusory. The Constitution provides no guide to the tasks that states have or should have performed in the past; judges consequently encounter problems of institutional competence similar to those confronted in the Ninth Amendment cases. In surveying and evaluating the powers that states have exercised, courts are forced to make policy judgments for which they are ill-equipped, ${ }^{38}$ concerning local conditions with which they

35. See Choper, The Scope of National Power Vis-à-Vis the States: The Dispensability of Judicial Review, 86 YAle L.J. 1552, 1554-57 (1977) (pragmatic, policy-oriented nature of federalism decisions makes them inappropriate subject for judicial review); Grodzins, Centralization $\mathcal{E}$ Decentralization in the American Federal System, in A Nation of STATES, supra note 32, at 1, 1-4 (state and federal powers are shared on random or pragmatic basis rather than divided along rigid, normatively prescribed lines); Note, supra note 32, at 163 (pragmatic reality of federalism decisions must be separated from normative "myths" surrounding them before appropriate judicial role can be prescribed).

36. But see Kirkpatrick, The Case for "States' Rights," in A Nation of States, supra note 32, at 91, 100-05 (incorporates normative claims for state power in broad argument for shifting balance of federalism toward states); Nagel, Federalism as a Fundamental Value: National League of Cities in Perspective, 1981 Sur. CT. REv. 81, 100-09 (states can effectively counterbalance national power, if their sovereignty and sources of legitimacy are protected in opinions such as National League of Cities).

37. The term "traditional state function" was first used by the Supreme Court in United Transp. Union v. Long Island R.R., 455 U.S. 678, 684 (1982). In National League of Cities, Justice Rehnquist refers to these functions as "integral governmental functions" or "traditional aspects of state sovereignty." 426 U.S. at $845,849,851$ (1976).

While the "traditional state function" standard was introduced by National League of Cities, the enterprise of identifying characteristically local functions dates back to the commerce clause cases of the early twentieth century. In these cases and their progeny, the Court attempted to distinguish activities which were purely local in nature, and therefore not subject to congressional regulation under the commerce power, from those which were national or interstate in character, and therefore subject to that power. See, e.g., Wickard v. Filburn, 317 U.S. 111, 118-20 (1942) (describing practice of distinguishing activities before abandoning practice in favor of test of economic impact); United States v. Darby, 312 U.S. 100, 118-20 (1941); Hammer v. Dagenhart, 247 U.S. 251, 273-74 (1918). The Court's early experience in distinguishing these functions rapidly collapsed into a series of judicial ipse dixils which provided neither explanation for the decision in a given case nor guidance for the future. Compare Hammer v. Dagenhart, 247 U.S. 251 (1918) (regulation of conditions of child labor matter of purely local concern) with United States v. Darby, 312 U.S. 100 (1941) (conditions of child labor appropriate subject for congressional regulation).

38. See Choper, supra note 35, at 1554-57. 
are unfamiliar. ${ }^{39}$ These institutional problems have been reflected in the case law that has emerged. The spate of lower court decisions employing this approach ${ }^{40}$ has failed to produce a coherent standard for limiting federal power under the commerce clause. ${ }^{41}$

Both normative and empirical approaches have failed for the same reason: Each requires that judges take their bearings from sources inappropriate for judicial consideration. Judges do not possess a Gallup Poll with which to determine "conventional morality," 42 nor are they trained to compare normative political theories. ${ }^{43}$ Yet when these methods fail, courts are left to their own resources, to create the crazy-quilt of conflicting interpretations that covers this field today.

A third approach, the analysis of "structure and relationship," attempts to avoid these pitfalls. This method takes its bearings from the Constitution, drawing inferences from the governmental structures and relation-

39. Particularly in cases where courts have held that "traditional" should be given a flexible meaning to adapt to changing needs and times, see infra note 40 , they have been obliged to evaluate local conditions in order to determine whether an activity constitutes a "traditional" or "integral" state function. See United Transp. Union v. Long Island R.R., 634 F.2d 19, 26-27 (2d Cir. 1980) (considering whether need for commuter railroad made it necessary for state to undertake its administration), rez'd, 455 U.S. 678 (1982).

40. See, e.g., Kramer v. New Castle Transit Auth., 677 F.2d 308, 309-10 (3d Cir. 1982) (history central in defining "traditional governmental function"); United Transp. Union v. Long Island R.R., 634 F.2d 19, 26-27 (2d Cir. 1980) (not only history but "new development[s]" and need for "public service" define "integral governmental function"), rev'd, 455 U.S. 678 (1982); Amersbach v. City of Cleveland, 598 F.2d 1033, 1037-38 (6th Cir. 1979) (four-part test, including criterion which measures "appropriateness" of government function in light of "communitywide need," defines "traditional governmental function"). The confusion reached sufficient proportions for the Supreme Court to note probable jurisdiction in San Antonio Metropolitan Transit Auth. v. Donovan, 52 U.S.L.W. 3261 (U.S. Oct. 3, 1983). The district court there had established a six-part test, whose elements included the history of the federal regulation involved, the Amersbach tests, and an analogy to $\mathrm{Na}$ tional League of Cities functions.

Courts applying "traditional state function" analysis to antitrust cases, in order to determine the activities to which the "state action" exception to the Sherman Act should apply, have encountered similar difficulties. See Jefferson County Pharmaceutical Ass'n v. Abbott Laboratories, 656 F.2d 92, 97 (5th Cir. 1981) (Clark, J., dissenting) (conflating "traditional state function" standard with normative "states as states" standard); Hybud Equip. Corp. v. City of Akron, 654 F.2d 1187, 1196 (6th Cir. 1981) (vacillating between emphasis on history and insistence that conceptions of traditional state activities change "to meet changing times").

41. The courts have even differed over how to decide which state functions are "traditional." Compare Kramer v. New Castle Area Transit Auth., 677 F.2d 308, 309 (3d Cir. 1982) ("the historical reality of the activity in question could not be ignored") and United States v. Best, 573 F.2d 1095, 1103 (9th Cir. 1978) (licensing of drivers is service which "States and their political subdivisions have traditionally afforded their citizens") with cases discussed supra note 40 (meaning of "traditional" must change to meet changing times).

At least one court appended to its historical analysis an ad hoc inquiry into whether the function was one which the government was particularly suited to provide because of local needs. See Amersbach, 598 F.2d at 1037-38 (municipal government "particularly suited [to operate airport] because of a communitywide need").

42. See Griswold v. Connecticut, 381 U.S. 479, 519 (1965) (Black, J., dissenting).

43. See J. ELY, supra note 8, at 56-60. Ely suggests the incongruity of this approach by imagining a judicial foray into normative analysis: "We like Rawls, you like Nozick. We win, 6-3. Statute invalidated." Id. at 58. 
ships established by the document as a whole. The structural approach offers a point of reference that is both determinate, when compared with sources such as natural law and "conventional morality," and ideally suited to judicial competence. In the hands of Charles Black, the analysis of structure and relationship has produced the most cogent available interpretation of the Ninth Amendment. ${ }^{44}$ This Note argues that the approach is even better suited to giving content to the Tenth.

\section{The Structures of Constitutional Meaning}

The Ninth and Tenth Amendments, on first inspection, appear perfect subjects for structural interpretation. They concern rights and powers not specifically mentioned, but nonetheless enjoyed by those living under the Constitution. To determine the kind of rights and powers these might be, one might logically consider the general features of the governmental system with which they coexist. Charles Black, who pioneered this approach, has used structural analysis to construe the Ninth Amendment. An examination of several of the rights he has discovered provides insight into the structural approach and the range of liberties it may be used to protect. ${ }^{40}$

\section{A. The Ninth Amendment: An Embarassment of Riches?}

The most obvious point of departure is the political rights that may be inferred from the constitutional structure. The Constitution, above all, establishes a political regime: a participatory democracy that accords its citizens the right not only to vote, but to develop and disseminate political views. ${ }^{16}$ Many of these participatory rights are explicitly protected. ${ }^{47}$ Yet other, analogous rights implied by the political structure have been neglected by courts insistent on a narrow, language-based interpretivism. ${ }^{48}$

44. See supra note 8 .

45. No such listing can be inclusive. Professor Black, who has said that the corpus of rights protected by the Ninth Amendment "will never be built; it will always be building, like the common law," C. Black, On Reading and Using the Ninth Amendment, supra note 8, at 11, views this breadth as one of the amendment's greatest assets. See Decision According to LAw, supra note 8, at 48; C. Black, supra note 8, at 11-12. This Note examines one method-the structural method-by which Black derives unenumerated rights from the Constitution.

46. The idea that the Constitution created, first and foremost, a political regime is also the point of departure for the constitutional theory of Judge Bork. See Bork, supra note 20, at 17-18. But Bork suggests that it is possible to derive only political rights from a structure which is predominantly political, while Black contends that one can derive "private" as well as public or political rights from that same structure. See infra pp. 733-34.

47. Spe U.S. CoNST. amend. I "Congress shall make no law . . . abridging the freedom of speech, or of the press; or the right of the people to peaceably assemble, and to petition the Government for a redress of grievances."); id. amend. XV ("The right of citizens of the United States to vote shall not be denied or abridged by the United States or by any State on account of race, color, or previous conditions of servitude."); $i d$. amend. XIX ("The right of citizens of the United States to vote shall not be denied or abridged by the United States or by any State on account of sex.").

48. See Decision According to Law, supra note 8, at 49-53. 
But why, Black asks, should a speech that could not be prevented by a congressional enactment be prevented by a judge's gag order?49 And why, one might ask, should a group of citizens who could not be denied the vote by reason of race or gender be denied the vote by reason of ethnicity, socio-economic level or any other petty prejudice indulged by election officials? The broad terms of the Ninth Amendment supply the proper instrument for protecting all rights concomitant to the political structure. ${ }^{80}$

Also incorporated in the structure of our government is a far-ranging requirement that citizens be treated equally. ${ }^{51}$ This fundamental concern with the equal treatment of its citizens, Black argues, should not be circumscribed by the narrow language of the specific clauses that help to convey it. When a claim for equality is made that falls outside the categories established by such language-but that is analogous to them-such a claim should be protected by the Ninth Amendment. ${ }^{62}$ This amendment can extend the equal protection of the laws to groups beyond the historically narrow "suspect classifications"ss and provide relief to those injured by discriminatory behavior not perpetrated by government agents. ${ }^{54}$

49. Id. at $48-49$.

50. Black argues that the Ninth Amendment also has the advantage of making the guarantees inferable from the constitutional structure enforceable against the states. Id. at 46-47. While firmly grounded in the doctrine of "incorporation," see Adamson v. California, 332 U.S. 46 (1947) (rights "implicit in the concept of ordered liberty" are incorporated in Fourteenth Amendment as applicable against states), this inference has been the subject of considerable controversy. Compare Griswold v. Connecticut, 381 U.S. 479, 493 (1965) (Goldberg, J., concurring) ("[T]he Ninth Amendment is relevant in a case dealing with a State's infringement of a fundamental right. While the Ninth Amendment . . . originally concerned restrictions upon federal power, the subsequently enacted Fourteenth Amendment prohibits the States as well from abridging fundamental personal liberties.") with id. at 520 (Black, J., dissenting) (for "a century and a half, no serious suggestion was ever made that the Ninth Amendment, enacted to protect state powers against federal invasion, could be used as a weapon of federal power to prevent state legislatures from passing laws they consider appropriate to govern local affairs") and Berger, supra note 8, at 24 (federal enforcement of Ninth Amendment against states "blatantly perverts the meaning of the framers").

51. See U.S. Const. amend. V (federal government must employ due process when it deprives any citizen of life, liberty, or property); id. amend. XIII (proscribing involuntary servitude); id. amend. XIV (states must employ due process when they deprive any citizen of life, liberty, or property and must accord all citizens equal protection under their laws).

52. See Decision According to LAw, supra note 8, at 61-62 (aliens should be granted equal protection of the laws).

53. See id. at 56, 61, 73. An approach which Black finds preferable to "suspect classification" analysis is to distinguish between blacks and other minorities, not in the degree of constitutional protection they receive, but in the source of such protection. The rights of blacks could be protected under the broad prohibitions of the Fourteenth Amendment, and the rights of other minorities under the general terms of the Ninth. Id. at 73 (rights of women, inferable by analogy, should be protected under Ninth Amendment).

54. See Structure and Relationship, supra note 8, at 17-23. Referring to Brewer v. Hoxic School Dist. No. 46, 238 F.2d 91 (8th Cir. 1956), a case in which the court extended the Fourteenth Amendment to invalidate private interference with desegregation, Black argues that a more direct answer could have been obtained through structural analysis. It would have been possible, Black argues, to infer from the federal-state relationship "that people were forbidden to interfere with state officials who were trying to implemeited Transp. Union v. Long Island R.R., 455 U.S. 678 (1982) (application of Railway Labor Act to employees of state-owned railroad does not violate Tenth 
As the last example suggests, the rights that one can infer from constitutional structure need not relate merely to citizens' political activities or even to their interaction with the government. The "structure of [American] citizenship," Black contends, also guarantees the "right to lead a private life." claim, $^{\text {se }}$ one can infer it from the Constitution itself. The Constitution creates a limited government that refrains both from making any aspect of political life compulsory and from interfering in the private lives of its citizens, except under constitutionally specified conditions. These features convey the crucial understanding that the American citizen is a private individual as well as a public actor, ${ }^{57}$ and that the portion of his life spent in the former realm is as deserving of judicial solicitude as the portion of his life spent in the latter. ${ }^{\mathrm{s}}$

The much-discussed "right to privacy" therefore flows naturally from a structural analysis. Many constitutional provisions protect the integrity of the home: The Third and Fourth Amendments protect it from unwarranted intrusion, and the Fifth protects the property that comprises it from uncompensated appropriation. Still other provisions evince a concern for the integrity of the physical person: The due process clause was originally concerned with "liberty" from physical confinement, ${ }^{59}$ and the Thir-

Amendment); Hodel v. Virginia Surface Mining \& Reclamation Ass'n, 452 U.S. 264 (1981) (Surface Mining and Reclamation Act of 1977 does not violate Tenth Amendment). The National League of Cities doctrine suffered its greatest curtailment to date in last Term's decision in EEOG v. Wyoming, 103 S. Ct. 1054 (1983). There, the Court held that the it is far more comprehensive than those drawn by other structural analysts. See supra note 46 (Bork infers only political rights from constitutional structure); P. BobBitT, Constrtutional Fate: Theory of the Constrrution 89 (1982) (criticizing Bork's inference as too narrow, but failing to conclude that private rights can also be inferred from political structure).

55. Black, see Unfinished Business of the Warren Court, 46 WASH. L. REv. 3, 8-9 (1970).

56. Black sees its vindication in the decisions of the Warren Court.

57. See generally Ackerman, Discovering the Constitution, 93 YALE L.J. (forthcoming). Ackerman sees the dualistic quality of American citizenship as one of the distinguishing features of the American constitutional regime. It is the tendency of American citizens to focus primarily on their private concerns that gives their moments of self-conscious political activity particular saliency and constitutional importance.

58. Among the "private rights" that flow from the constitutional structure is the right to travel. This may be Professor Black's most instructive example, for it is mentioned nowhere in the Constitution, yet one can easily infer it by structural analysis. In Crandall v. Nevada, 73 U.S. (6 Wall.) 35 (1867), the case in which the right to travel was first recognized, the Court reasoned that the Constitution established a participatory democracy, and the prerequisites of such a democracy-that citizens vote and that they take part in widespread political activity-required that they be permitted to travel within the nation as they wished. While Black applauds the Court's use of structural analysis, he claims that a more comprehensive structural argument can be made. The Constitution, Black observes, established a unitary nation out of thirteen small republics; "in a unitary nation . . . because of its nationhood, internal barriers to travel are unthinkable . . . STRUCTURE AND RELATIONSHIP, supra note 8 , at 29 . Black's approach permits inferences not simply from the structure of the government but from the structure of the nation as well.

59. See R. Berger, supra note 20, at 270. Berger explains that Blackstone defined individual liberty as "the power of loco-motion ... or removing one's person to whatsoever place one's own inclinations may direct; without imprisonment or restraint, unless by due course of law." 1 W. 
teenth Amendment prevents one man from using another's body as he wills. These clauses taken together suggest a solicitude toward the nonpublic citizen that can be comprehended by the term "privacy." Decisions relating to home and family life-including the conception, ${ }^{60}$ bearing, ${ }^{61}$ and rearing of children ${ }^{62}$ - can be protected from governmental interference by such an inference. ${ }^{63}$

This example does, however, highlight the difficulty of using structural analysis to discover unenumerated rights. There are a great many rights in the Constitution not organized in any identifiable hierarchy. This constitutional pluralism reveals both the potential breadth of Ninth Amendment protection and its distinctive dangers. A judge may be tempted to impose his own hierarchy by reverting to a "fundamental rights" approach. ${ }^{64} \mathrm{He}$ may also fall into an infinite regress of analogic reasoning, in which he draws inferences from rights that are themselves inferences, vitiating the original advantage of constitutional guidance. These problems do not emerge so strikingly in cases where rights are drawn from a well-

Blackstone, Commentaries *134. This definition was, moreover, presented to the House during the debates over the Fourteenth Amendment. See R. BERGER, supra, at 270.

60. See, e.g., Eisenstadt v. Baird, 405 U.S. 438 (1972) (invalidating regulation making contraceptives less available to unmarried than to married couples); Griswold v. Connecticut, 381 U.S. 479 (1965) (invalidating ordinance imposing criminal penalty for use or prescription of contraceptives).

61. See, e.g., City of Akron v. Akron Center for Reproductive Health, 103 S. Ct. 2481 (1983) (invalidating statute placing restrictions on availability of abortions); Roe v. Wade, 410 U.S. 113 (1973) (invalidating statute prohibiting non-therapeutic abortions).

62. See, e.g., Moore v. City of East Cleveland, 431 U.S. 494 (1977) (striking down law that prevented grandmother from having her grandson live with her); Pierce v. Society of Sisters, 268 U.S. 510 (1925) (striking down law requiring children to attend public schools).

63. While the rights protected by the Ninth Amendment may be asserted against a broad range of parties, see supra notes 50,54 , they are limited in one salient sense. They may be asserted only by individuals, not by corporate entities or groups. A parent, for example, may claim a Ninth Amendment right to place his child in the school of his choice, see supra note 62 , but a city may not claim a Ninth Amendment right to withdraw its children from a county school system, even if this action conforms with the wishes of the parents, see Gewirtz, Remedies and Resistance, 92 YALE L.J. 585, 636-37 n.133 (1983) ("corporate" withdrawal or white flight is one means of evading desegregation decrees). In this respect, the rights protected by the Ninth Amendment differ from the powers reserved "to the people" under the Tenth Amendment. See infra pp. 738-40. These reserved powers inhere in the people of the state, as a collectivity, and may be asserted by them in that capacity.

64. "Fundamental rights" theories, which include those "natural law" theories discussed supra note 17 , claim that the Constitution establishes or embodies an ordering of rights. See, e.g., Olff v. East Side Union High School Dist., 404 U.S. 1042, 1044 (1972) (Douglas, J., dissenting from denial of certiorari) ("liberty" as used in Fourteenth Amendment and implied by the Ninth Amendment comprehends "fundamental rights"); Griswold v. Connecticut, 381 U.S. 479, 488 (1965) (Douglas, J.) ("liberty" as used in Fourteenth Amendment protects right of privacy "created by several fundamental constitutional guarantees"); Poe v. Ullman, 367 U.S. 497, 539-45 (1961) (Harlan, J., dissenting) (Fourteenth Amendment due process clause protects rights "implicit in the concept of ordered liberty"); Palko v. Connecticut, 302 U.S. 319, 325 (1937) (same standard). The primary problem with these theories is that they require judges to decide which rights are "fundamental," guided only by philosophical sources which are inappropriate for their consideration. See supra p. 726; Brest, The Fundamental Rights Controversy: The Essential Contradictions of Normatize Scholarship, 90 YALE L.J. 1063, 1080-89 (1981) (surveying arguments of fundamental rights critics such as Ely, Bork and Berger, who assert that fundamental rights theories do not provide the principled judicial guidance that proponents claim). 
articulated constitutional structure, such as the political structure or the structure of nationhood discussed above. ${ }^{85}$ But where rights are grounded solely on those inferences that can be drawn from other rights, placing limits on the process of inference can be difficult.

For these reasons, one encounters fewer problems in inferring the unenumerated powers protected by the Tenth Amendment. The Framers drafted the institutional provisions of the Constitution with greater clarity and organization. Not only does the document set out in detail the powers of each institution, but it relates them through a broad structure of checks and balances to the powers exercised by other institutions. The constitutional outline of the federal system, while less explicit as a whole, follows the same general pattern. The first four articles prescribe powers and prohibitions relating to the state and national governments; the Tenth Amendment suggests a broad relationship of complementary action between them. From this structure of federalism and the more detailed structure of the national government, it is possible to infer-with even greater success than in the Ninth Amendment area-the contours of the sovereignty that inheres in the states and their people.

\section{B. The Tenth Amendment: Reasoning to "State Sovereignty"}

A structural inquiry into the Tenth Amendment ${ }^{88}$ should begin by examining the position of the states in the articles of the Constitution itself.

65. See supra pp. 732-33.

66. Bobbitt argues that structural analysis has already been applied to the Tenth Amendment, in the majority opinion of National League of Cities. SPe P. BoBBIrT, supra note 56, at 75. A brief consideration of Bobbitt's analysis of that opinion, however, reveals the error of this claim. In Bobbitt's view, National Lengue of Cities is based on a three-step analysis:

(1) the Constitution sets up a federal structure necessarily providing for states;

(2) states must perform those functions integral to being states without congressional regu-

lation, or the relationship established by the Constitution between the federal and state struc-

tures would become the assimilation of one structure into the other;

(3) it is plausible to conclude that determining the wages and hours of its employees is one of those fundamental state activities as to which state authority should be sovereign, within the various provisions of the Constitution.

Il. at 75. While this description provides an accurate encapsulation of National League of Cities, it is not an example of a structural argument. The first step of the argument moves in the right direction: Our constitutional structure provides, at the very least, for the existence of the states. The second step, however, takes an unexpected and erroneous detour. If the constitutional structure provides, at the very least, for the existence of the states, the next step should be: (1) whether the challenged enactment threatens the existence of the states, or (2) whether the Constitution protects something more than the existence of states which might be imperiled by the enactment. The Court's argument, as described by Bobbitt, does neither. It creates a category of "functions integral to being a State" that makes no reference to the Constitution or to any constitutional concomitants of statehood. Both this departure from the text and Bobbitt's choice of a new term ("functions integral") suggest that his inquiry is headed toward the realm of political philosophy. Bobbitt confirms this normative orientation in the third step of his argument, where he lapses into a hypothetical discussion of the state function in question: He finds it plausible that determining the wages of state employees is one of these integral functions. This speculation avoids the question of whether the Constitution designates, or even alludes to, such a function as a feature of statehood. It also calls up the image of an entire 
The states are, at the most basic level, the geographic subdivisions of the nation. They are the units over which the census is taken and among which taxes are apportioned. ${ }^{67}$ Yet their inclusion in the constitutional structure was more than an acknowledgment of then-existing physical divisions. The Constitution requires the federal government to defend the states in case of invasion or internal insurrection, ${ }^{68}$ and to secure their permission before merging them. ${ }^{68}$ The suggestion of these clauses-that the states enjoy a distinctive position in the constitutional system-is confirmed by their inclusion in many of the institutions of the federal government. States are embodied, as equal and autonomous units, in the U.S. Senate; ${ }^{70}$ they are accorded votes in the electoral college that selects the President; ${ }^{71}$ they may invoke the original jurisdiction of the Supreme Gourt when they are parties to a lawsuit. ${ }^{22}$ The states are regarded within the system as political subdivisions that are expected to express the will of their citizens on matters of national importance and of concern within their own boundaries.

Nor is political activity by the states limited to participation in the national government. Article IV guarantees to each of the states a republican form of government, ${ }^{73}$ suggesting that they are entitled to some degree of self-determination. And although firm boundaries are placed on their independence by the needs of a unified national government-state legislatures may not enter into treaties, ${ }^{74}$ engage in war $^{75}$ or impose duties on imports $^{76}$ - the purpose of these bodies is more than ceremonial: They are intended to reflect and implement public sentiment on a range of internal

class of "plausible" concommitants to statehood which can be developed according to the theoretical predilections of the commentator. "[I]t follows from the very structure of . . . federalism created by the United States Constitution," Bobbitt concludes in defense of his speculation, "that there must be at least some such activities." Id. It follows from the structure of federalism that the Constitution provides additional guidance in identifying such activities, and that one who claims to employ a structural method should consult the text for direction.

67. U.S. Consr. art. I, $\S 2$, cl. 3.

68. Id. art. IV, $\S 4$.

69. Id. art. IV, \& 3, cl. 1.

70. Id. art. I, $\S 3$, cl. 1 .

71. Id. art. II, $\S 1, \mathrm{cl} .2$.

72. Id. art. III, $\S 2$, cl. 2.

73. Id. art. IV, \& 4. The guarantee clause has been held for many years to be unenforceable by the courts. See, e.g., Baker v. Carr, 369 U.S. 186, 224 (1962) (challenges to congressional action based on inconsistency with guarantee clause present no justiciable question); Luther v. Borden, 48 U.S. (7 How.) 1 (1849) (guarantee clause does not authorize federal court to determine which of two governments is the legitimate government of a state). Some scholars have recently argued, however, that the guarantee clause should be interpreted as having justiciable, substantive content. See, e.g., J. ELY, supra note 8, at 122-23 ("republican form" clause can and should be used to prevent denial and dilution of franchise); Note, The Rule of Law and the States: A New Interpretation of the Guarantee Clause, 93 YAL.E L.J. 561 (1984) (guarantee clause should protect "rule of law" in state procedures).

74. U.S. ConsT. art. I, $\S 10$, cl. 1 .

75. Id. art. I, $\S 10, \mathrm{cl} .3$.

76. Id. art. I, $\S 10$, cl. 2 . 
issues. This provision thus reinforces the inference that the characteristic activity of a state is the articulation, through a process of representation, of the political opinions and preferences of its citizens.

The Tenth Amendment imparts the further direction that powers not delegated to the national government are reserved to the states or to the people. This provision suggests that the federal government is a government of limited powers, but it also establishes a broad relationship of complementarity between the federal and state governments. The states may not exercise the powers delegated to the federal government-a message also implied in the prohibitory provisions of Article $\mathrm{I}^{77}$ Moreover, the federal government may not exercise the powers properly reserved to the states. This latter inference-raised only by the Tenth Amendment-supports the Court's analysis that there are activities of the states upon which the powers of the federal government may not intrude.

The Constitution does not explicitly state which activities are in the presumptive domain of the states, but the structure of the system as a whole implies the beginning of an answer. The states are presented as political units that represent the will of their citizens through legislative activity. This activity is undertaken not only in the national legislature but through the "republican" institutions of the state. The latter activity is more likely to be the subject of Tenth Amendment litigation: Federal enactments that compromise the political or legislative processes of the state would appear most likely to infringe what might be called the "sovereignty" of the states. ${ }^{78}$

It is more difficult to determine what kind of enactments might "compromise" this characteristic activity, for the Constitution provides little prescriptive detail concerning state political processes. The lower courts have tried to fill this gap by importing the concept of "traditional state

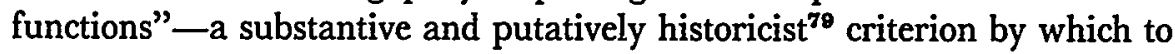

77. See supra notes 74-76 (states may not make treaties, impose duties on imports, or enter into war).

78. Nowhere in the Constitution is there any reference to the "sovereignty" of the states. Thus the very introduction of the term raises the inference that the Court is attempting to supplement the provisions of that document with an independent theory of state power. The frequency of the term "sovereignty" in the classic works of political philosophy suggests the normative origins-and orientation-of the Court's approach.

79. The Constitution does not place substantive tasks-such as the administration of parks or transportation-in the hands of the states. While this omission may reflect the difficulties of a comprehensive listing, other factors provide a superior explanation. The tasks necessary to state administration vary according to time and place. They may, moreover, be pre-empted by the legitimate activities of the national government, an inference supported both by the supremacy clause and by Article I's prohibition on exercise by the states of those powers which should be exercised by a uniform, national authority. See p. 736.

The courts' emphasis on substantive tasks also leads some courts to conclude that any enterprise necessary or helpful to the "effective functioning of the states" is an "integral" component of "state sovereignty." See National League of Cities v. Usery, 426 U.S. 833, 846-52 (1976) (imposition of 
measure the severity of federal intrusions. This choice has, however, been an error from a constitutional standpoint: It focuses the courts' attention on activities of local administration that are totally distinct from the kinds of activities described by the Constitution. It also introduces a substantive criterion, which runs contrary to the procedural or institutional emphasis of the relevant provisions. ${ }^{80}$

When the Constitution refers to the states, it does not delineate substantive tasks; it establishes political institutions and participatory processes. This emphasis should be preserved in adjudicating the Tenth Amendment. Courts should be sensitive to enactments that still the states' legislative voices on determinations of obvious substantive importance. But courts should reserve their strictest scrutiny for enactments that attempt to alter or control substantial portions of the legislative process. This "process" should be considered to include both the deliberation and decisionmaking at the core of the legislative function, and the political participation and agenda-setting that occur through communication among legislators, executive agencies and constituent groups.

It would seem inconsistent-perhaps futile-to protect this process against federal interference without also securing it from infringement by the states themselves. Federal pre-emption of the state legislative agenda is not the only means of interfering with the expression and implementation of citizens' views. Poll taxes, "white" primaries, and discriminatory annexations ${ }^{81}$ strike at different parts of the legislative process, but have the same disruptive effect. If the Tenth Amendment were interpreted to proscribe such offenses, it would remove all barriers to political expression while giving content to the perplexing final clause of that provision-powers not delegated to the federal government are reserved "to the

minimum wage prevents states from structuring employment relations in most efficient way). This argument, however, was firmly rejected by the Court in EEOC v. Wyoming, $103 \mathrm{~S}$. Ct. 1054 (1983):

A state's employment relationship with its workers can, under certain circumstances, be one vehicle for the exercise of its core sovereign functions . . . . But we are not to be understood to suggest that every state employment decision aimed simply at advancing a generalized interest in efficient management-even the efficient management of traditional state functions-should be considered to be an exercise of an "undoubted attribute of state sovereignty."

103 S. Ct. at 1061 n.11.

80. See supra note 41 (discussing courts' varying uses of history in determining meaning of "traditional").

81. See Harper v. Virginia Bd. of Elections, 383 U.S. 663 (1966) (striking down state-imposed poll tax as requirement for voting); Gomillion v. Lightfoot, 364 U.S. 339 (1960) (striking down redefinition of municipal boundaries that eliminated virtually all black voters); Nixon v. Condon, 286 U.S. 73 (1932) (invalidating state party's exclusion of black citizens from state primary).

The right to vote in state elections is not expressly mentioned in the Constitution. It has sometimes been construed as implicit in the First Amendment's protection of a range of political rights. See Harper, 383 U.S. at 665 (Court offers but does not validate this interpretation). Protection of the right to vote-in either state or federal elections-against impairment or dilution by state governments has most often been achieved through the equal protection clause of the Fourteenth Amendment. See, e.g., Reynolds v. Sims, 377 U.S. 533 (1964); Gray v. Sanders, 372 U.S. 368 (1963). 
people." Long regarded as "something of a puzzle," these words could now be given determinate meaning: The Tenth Amendment reserves to the states the power to create and operate a responsive legislative system, but when this authority is abused the Amendment reserves to the people the power to express their will unimpeded. ${ }^{83}$

This element of the structural approach would reinforce and complement the final set of constitutional provisions defining state power-the Civil War Amendments. These amendments, products of a bitter struggle over the structure of the federal system, represent the most explicit effort to relate that structure to the constitutional rights of state citizens. Interpreted structurally, the Tenth Amendment would affirm the Civil War Amendments' central message: that the sovereignty of the states ends where the rights of the citizen begin. ${ }^{84}$ It might also supply a breadth of

82. Choper, supra note 35, at 1612 (quoting $1 \mathrm{~W}$. CRosskey, Polrics and the ConstituTION 702 (1953)). There has, of course, been no dearth of scholarly speculation. Some commentators have maintained that these words make the meaning of the Tenth Amendment conform to that of the Ninth. See Redlich, supra note 9, at 806-07. Others have interpreted these words to mean that any reserved powers not exercised by the states, through their state constitutions, may be exercised by the people. See 2 J. Story, Commentaries on the Constitution $\$ 1907$. The interpretation which bears most similarity to that advanced by this Note was offered, but not endorsed, by Justice Harlan in his dissent in Flast v. Cohen, 392 U.S. 83, 129 n.18 (1968). Here Justice Harlan speculated that the Ninth and Tenth Amendments could have been "intended to declare the standing of individual citizens to contest the validity of governmental activities." Id. Though his focus is primarily on standing and he does not explain whether "governmental" refers to federal or state authorities or both, Justice Harlan's argument bears some resemblance to this Note's position that citizens may have a Tenth Amendment claim against their state if it infringes the participational opportunities that the amendment was intended to secure.

83. Some governmental actions serve both to buttress state political processes against federal domination and to protect individual action within that process from state circumscription. One example is federal action prescribing state legislative reapportionment. Legislative or judicial action in this area increases the effectiveness of individual participation in the state political system; it also may strengthen the state legislative process and the position of the state legislatures relative to the federal government. In a 1967 article, Judge John Minor Wisdom observed:

[C]ities and suburban areas have been so underrepresented in some state legislatures that a

strong tendency has developed toward federal-municipal dealings that bypass state govern-

ments, thereby undermining effective state administration. Fair apportionment will lead to

more responsible state legislatures. In the long run, this now unwanted intrusion of the federal

courts into state affairs will strengthen the states and their local communities vis à vis the

federal government. There will be less need for city officials to run to Washington for help. Wisdom, The Frictionmaking, Exacerbating Political Role of the Federal Courts, 21 Sw. L.J. 411, 417 (1967). It seems plausible that those actions which secure the powers of both the states and "the people" most deserve the protection of the Tenth Amendment.

84. This argument may be met with the objection, analogous to that raised by Berger, supra note 8, that the last thing the Tenth Amendment was intended to do was to enlarge the enforcement powers of the federal government as against the states. This interpretation would be tenable were it not for the inclusion in the Amendment of specific language reserving unenumerated powers "to the people." This language, which resembles and previews the language of the Civil War Amendments, suggests that there are activities or opportunities connected with membership in the American polity which may not be infringed, even by the states acting in their sovereign capacity. These activities may be discovered by determining, by structural inference, the range of powers reserved to the states; state powers, as demonstrated above, are directly related to the preservation of these opportunities. Yet while the states may be the primary protectors of such opportunities, they do not enjoy the license to infringe them at will. When infringement is perpetrated by a state, it falls to the federal government, 
protection that the Civil Rights Amendments have been largely unable to provide. ${ }^{85}$ Because the Tenth Amendment, as interpreted above, draws no distinctions among possible sources of infringement, it could be used to secure political participation not only from state action but from the interference of private parties. ${ }^{88}$

\section{Structure and its Implications: A New Tenth AMENDMENT JURISPRUDENCE}

The structural approach places adjudication of Tenth Amendment issues squarely within the competence of the federal courts. It focuses their scrutiny on the Constitution, whose language and structure it is their first responsibility to interpret and apply. And to the extent that the application of this approach required them to go beyond the document itself, it would direct their attention to the integrity or disruption of the legislative process-a type of judgment that the courts have proven competent to undertake. ${ }^{87}$

as the remaining authority in the federal system, to protect these opportunities. $C f$. THE Federalist No. 51, at 323 (J. Madison) (J. Cooke ed. 1961) (federal system provides double protection in that one government can enforce citizen's rights when other does not).

85. The "state action" requirement of the Fourteenth and Fifteenth Amendments, which dates back to The Civil Rights Cases, 109 U.S. 3 (1883), has been the subject of extensive scholarly attention. See, e.g., Black, Foreuord: "Stale Action," Equal Protection and California's Proposition 14, 81 HARv. L. REv. 69 (1967) (state action requirement, which "immunizes racist practices from constitutional control," should be retired); Karst \& Van Alstyne, State Action, 14 STAN. L. REv. 3 (1961) (state action requirement reflects important associational freedom interests, which should be preserved by careful judicial attention to facts of state involvement). In recent decades, courts have extended Fourteenth and Fifteenth Amendment coverage to private actors who open their property to public uses, see Marsh v. Alabama, 326 U.S. 501 (1946), whose activities comprise an integral part of the state electoral machinery, see Smith v. Allwright, 321 U.S. 649 (1944), or whose activities have an identifiable "nexus" with state action, see Shelley v. Kraemer, 334 U.S. 1 (1948), or entail "significant" state involvement, see Burton v. Wilmington Parking Auth., 365 U.S. 715 (1961). The state action requirement continues to limit judicial action, however, despite these broadening interpretations. See Rendell-Baker v. Kohn, 457 U.S. 830 (1982) (state funding and regulation not sufficient involvement to subject employment decisions of private school to Fourteenth Amendment); Blum v. Yaretsky, 457 U.S. 991 (1982) (state regulation and funding not sufficient state involvement to subject discharge decisions of private health care facility to Fourteenth Amendment).

86. The Tenth Amendment could thus be used to broaden the scope of the protection implied by the Fourteenth and Fifteenth Amendments much as Charles Black proposed to use the Ninth Amendment to extend the Fourteenth Amendment's guarantee of equal protection to minorities other than blacks. See supra note 53.

87. See J. Ely, supra note 8, at 102-04. Ely cites two factors that give judges an advantage in such adjudication. First, as lawyers, they are experts on process-not only "the processes by which facts are found and contending parties are allowed to present their claims," but "the processes by which issues of public policy are fairly determined . . "Id. at 102. Second, as non-legislative officials enjoying life tenure, they are sufficiently removed from the legislative process and its electoral sanctions to offer a comparatively objective account of what they see there. Id. at 103.

The structural approach offered here thus bears a resemblance to Ely's method, both in its emphasis on process and in its origins in footnote four of the Carolene Products case. See United States v. Carolene Prods. Co., 304 U.S. 144, 152-53 n.4 (1938). Yet the value which it protects is not the equality embodied in the footnote's commitment to "discrete and insular minorities" but rather the liberty inherent in its presumption against legislation that "restricts . . . political processes." Id. 
The structural approach would mandate a departure from the holdings of several recent Tenth Amendment cases. The enactment struck down in National League of Cities, for example, would probably have been upheld under a structural standard. Requiring states to pay their employees the minimum wage involved no alteration of the legislative agenda and placed only that single constraint on state decisionmakers. These facts, supported by the substantive consideration that the wages of state employees were not a matter of supervening import, would have assured an outcome different from that handed down by the Court.

A structural approach, on the other hand, would have invalidated the legislation upheld in FERC v. Mississippi. ${ }^{\mathbf{8 s}}$ Not only did the enactment concern the area of energy regulation, arguably of greater concern to state legislators than the minimum wage of municipal employees, but it also prompted substantial intrusion into the regulatory process. Some of the statute's provisions, such as those requiring state administrative tribunals to adjudicate disputes arising from the implementation of federal regulations, did not trench upon those expressive or legislative activities at the core of the states' constitutional definition. ${ }^{89}$ Other provisions, such as the requirement that state utility commissions consider adoption of specific rate designs and provide statements of reasons when federal standards are not adopted, clearly did. These directives interfered with regulatory activity of a legislative nature, not only by prescribing legislative outcomes but by usurping the power of the commissions to establish their own agendas. The Act circumscribed state legislators' capacity to respond flexibly to local problems, and undercut their ability to express the views and prefer-

88. 456 U.S. 742 (1982).

89. The state utilities commissions whose activities were at issue in FERC are unusual subjects for structural analysis, both because they were not, narrowly speaking, a part of the state legislative process and because the Act required the commissions to perform a variety of functions. Absent clear evidence of a delegation of state legislative power, the extent of permissible interference with such bodies is best analyzed by reference to the functions they perform. This "functional" approach has been used by the Court to determine the scope of presidential power to remove agency administrators. Sep Humphrey's Ex'r v. United States, 295 U.S. 602, 624-26 (1935) (President not empowered to remove director of FTC at will, because functions of agency are not executive but rather legislative or judicial in nature).

According to this analysis, interference with functions judicial in nature-such as the imposition of a requirement that state tribunals hear disputes arising from implementation of federal regulations-would not constitute a violation of state sovereignty. State judicial functions are not referred to in any of the constitutional provisions outlining the scope of state power, nor can they be considered a part of the legislative process accorded deference in those provisions. A structural approach would thus affirm the conclusion of the Court in Testa v. Katt, 330 U.S. 386 (1947), that the states must make their adjudicative tribunals available for the enforcement of federally created rights.

Structural analysis would not, however, support the extension of Testa to agency functions legislative in nature. The "power to make decisions and to set policy" for the state, FERC, 456 U.S. at 761, is an integral part of the legislative process, whether it be lodged in the state legislature or an administrative body. Thus federal enactments which interfere with such functions-such as the requirement that commissions evaluate federal rate designs and regulatory standards-infringe state sovereignty in violation of the Tenth Amendment. 
ences of their constituents. ${ }^{90}$ This disruption of the legislative process is precisely the sort of federal action that the Tenth Amendment should be used to prevent.

The structural standard would both support and strengthen the Court's decision in EEOC v. Wyoming. ${ }^{91}$ The application of the Age Discrimination in Employment Act, like that of the Fair Labor Standards Act at issue in National League of Cities, created no interference with the setting of the legislative agenda and affected the outcome of only one decision: the age at which state park employees would be required to retire. Structural analysis would not only affirm the decision to uphold the statute, but would impart additional content to the tests articulated by the Court. Under a structural standard, the "direct impairment" test-a procedural as opposed to substantive criterion-could become the primary focus of the courts' attention. Justice Brennan's two subordinate instructions would also acquire a new focus when interpreted in light of the structural approach. The first test, which measures the degree of interference with a "substantial stake"92 of the state in the regulated area, would require scrutiny of enactments that affect state decisions in areas of supervening substantive importance. The second, which assesses interference with "the ability [of the state] to . . . set priorities over a broad range of areas," "9s could function as the linchpin of structural analysis. It could be read to protect the range of agenda-setting and decisionmaking activities that comprise the state legislative process. ${ }^{94}$

A new Tenth Amendment jurisprudence would not, however, be limited in its application to federal enactments that compromise state decisionmaking processes. It would also proscribe interference by the states with the political expression of their citizens. This interpretation would

90. Justice O'Connor makes a similar point in her vigorous dissent. 456 U.S. at 787-90 (O'Connor, J., dissenting).

91. 103 S. Ct. 1054 (1983).

92. Id. at 1062 .

93. Id.

94. The Court will have an excellent opportunity to substitute this approach for the National League of Cities doctrine this Term in San Antonio Metropolitan Transit Auth. v. Donovan, 557 F. Supp. 445 (W.D. Tex. 1983), prob. juris. noted, 51 U.S.L.W. 3261 (U.S. Oct. 3, 1983). This case challenges the applicability of minimum wage and overtime provisions of the Fair Labor Standards Act to employees of a municipal mass transit system. The district court opinion, handed down only weeks before the Court's decision in EEOC $z$. Wyoming, testifies eloquently to the nonadministrability of the "traditional state function" standard. The court employed no less than five separate tests before concluding that the metropolitan transit service is a "traditional state function"-a decision rendered dubious by the Court's earlier decision that a commuter railroad could not be considered such a function, United Transp. Union v. Long Island R.R., 455 U.S. 678 (1982). Were the Supreme Court to reverse this holding, it would make applicable to the states the only statute ever definitively struck down as violative of the Tenth Amendment. Moreover, by resting this decision-either directly or by way of the EEOC \%. Wyoming tests described above-on the ground that the Fair Labor Standards Act does not disrupt the setting of the legislative agenda and affects only one minor legislative decision, the Court could pave the way for a sounder approach to Tenth Amendment adjudication. 
provide a firmer foundation for several pathbreaking decisions in the areas of political participation and voting rights. South Carolina v. Katzenbach ${ }^{95}$ for example, strained the enforcement provision of the Fifteenth Amendment to justify application of the Voting Rights Act to districts in which there had been no finding of a violation. ${ }^{96}$ Terry $v$. Adams ${ }^{97}$ employed a similarly expansive definition of state action to bring local political parties under the control of the Fifteenth Amendment. ${ }^{88}$ A structural interpretation of the Tenth Amendment could provide a superior rationale for both these decisions. Because the structural approach speaks in terms of affirmative opportunities for unimpaired participation rather than prohibitions on discriminatory behavior, the Amendment can be used to impose participation-reinforcing legislation and to subject private actors. to constitutional control in these and other cases. ${ }^{99}$

\section{CoNCLUSION}

This Note has sought to illuminate the contribution the Tenth Amendment could make both to substantive doctrine and to constitutional theory. It offers an enriched concept of state sovereignty, which protects not only the position of the states in the federal system, but the multifaceted political participation that their sovereignty was structured to secure. Moreover, by revealing the potential of structural analysis to impart determinate meaning to ambiguous texts, this analysis invites scholars, if not, indeed, the courts, to give this approach the serious attention it deserves.

-Kathryn Abrams

95. 383 U.S. 301 (1966).

96. The Court argued that, because Congress' enforcement power under $\S 2$ of the Fifteenth Amendment was comparable to its power under the "necessary and proper" clause, it could apply prophylactic measures in the absence of judicial findings of discrimination in order to advance the goals of the amendment. 383 U.S. at 325-27.

97. 345 U.S. 461 (1953).

98. Id. at 469 (state organization of electoral process in form which permits private associations to practice racial discrimination violates Fifteenth Amendment).

99. The affirmative character of Tenth Amendment protection does not, however, justify the imposition of wholly prophylactic legislation. The invocation of the amendment would depend on some showing that the states had failed to preserve the political participation whose protection was confided to them. Because the Tenth Amendment serves the value of liberty, rather than the principle of equality advanced by the Fourteenth Amendment, federal enforcement of its commands might not require the showing of intent associated with the Fourteenth Amendment. Cf. DEcision According to LAw, supra note 8, at 25-26 (structural interpretation of Ninth Amendment need not embody requisites of Fourteenth Amendment adjudication such as "state action" requirement). Under the Tenth Amendment standard, evidence of dilution or circumscription of individual participation might be sufficient to justify intervention. 